\title{
Zeolite as a Bone Bio-Modifier Carrier: An In-Vitro Study
}

\author{
Mobina Mousavi ${ }^{1}$, Azadeh Esmaeil Nejad ${ }^{2}$, Erfan Shamsoddin ${ }^{1}$, Mohammad Mehdi Golabgiran ${ }^{3} \&$ Behzad \\ Houshmand ${ }^{2}$ \\ ${ }^{1}$ School of Dentistry, Shahid Beheshti University of Medical Sciences, Tehran, Iran \\ ${ }^{2}$ Department of Periodontics, School of Dentistry, Shahid Beheshti University of Medical Sciences, Tehran, Iran \\ ${ }^{3}$ National Medical Device Directorate, Head of the Department of Dental Materials and Equipment, Ministry of \\ Health, Tehran, Iran \\ Correspondence: Behzad Houshmand, Periodontics Department, Dental School, Shaheed Beheshti University of \\ Medical Science, Tehran, Iran. Tel: +98-91-2806-3990. E-mail: Dr.b.houshmand@gmail.com
}

Received: May 25, 2019

Accepted: September 21, 2019

Online Published: October 23, 2019

doi:10.5539/jmbr.v9n1p126

URL: https://doi.org/10.5539/jmbr.v9n1p126

\begin{abstract}
Background: Zeolite is a microporous aluminosilicate compound which has been successfully used in tissue engineering. The effects of Zeolite on the morphology and functions of pre-osteoblastic MG-63 cells as new bone enhancer material is still unclear.

Methods: In this vitro experimental study, MTT and Alizarin red staining test were performed on six groups of MG-63 cells which differed in Zeolite $(Z)$ concentration and the presence or absence of Alloplast extract (A). Group A: $0.1 \mu \mathrm{g} / \mathrm{mL}$ Z+A, Group B: $0.1 \mu \mathrm{g} / \mathrm{mL}$ Z without A, Group C: $0.2 \mu \mathrm{g} / \mathrm{mL} Z+A$, Group D: $0.2 \mu \mathrm{g} / \mathrm{mL} \mathrm{Z}$ without A, Group E: $0.3 \mu \mathrm{g} / \mathrm{mL} Z+A$, Group F: $0.3 \mu \mathrm{g} / \mathrm{mL} \mathrm{Z} \mathrm{without} \mathrm{A.} \mathrm{There} \mathrm{were} \mathrm{also} \mathrm{three} \mathrm{control} \mathrm{groups} \mathrm{as}$ positive control, negative control, and Alloplast control based on each related test. The data were analyzed by SPSS 20 via one-way ANOVA and Welch test. $(\mathrm{P}<0.05)$.

Results: At 24 hours, results showed that solutions with $0.1 \mu \mathrm{g} / \mathrm{mL}, 0.2 \mu \mathrm{g} / \mathrm{mL}$, and $0.3 \mu \mathrm{g} / \mathrm{mL}$ Zeolite with or without Alloplast had significantly higher proliferation rates than positive control (distilled water) groups without Alloplast $(\mathrm{p}<0.001)$. At 72 hours time point, the results showed significantly higher proliferation rates in the solutions with $0.1 \mu \mathrm{g} / \mathrm{mL}, 0.2 \mu \mathrm{g} / \mathrm{mL}$, and $0.3 \mu \mathrm{g} / \mathrm{mL}$ Zeolite with or without Alloplast compared to the positive control group without Alloplast $(\mathrm{p}<0.001)$.

Conclusions: Zeolite can increase proliferation of MG-63 cells without presence of Alloplast; It seems that combination of Zeolite with Alloplast maybe enhancing proliferation and function of MG-63 cells.
\end{abstract}

Keywords: Zeolite Solution, Osteoblastic Morphology, Osteoblastic Activity, MG-63 Cells, Alloplast

\section{Introduction}

The bone has a dynamic structure consisting of a mineralized extracellular matrix, Osteocytes, Osteoclasts, blood vessels and nerves. A critical health issue can be the bone injury subsequent to traumas, resorption, and pathologic or physiologic destructions which offers bone regeneration process as a crucial aspect of regenerative medicine.

Reproducing of a lost or a damaged part of the body to recover the structure and function of the tissues is termed regeneration (Ranganath \& Nasim, 2017). The term "Bone regeneration" refers to the reparation of injured or lost bone tissue so that both structural and functional integrity will be provided (Gao et al., 2014). Regeneration of injured tissue is a priority of tissue engineering (Yeganeh, Athari, Tavakoli, \& Moghtadaei, 2018; Denisova, Suprunchuk, \& Dronova, 2017). So, the bone regeneration can be accomplished by this techniques which has three main prerequisites namely (scaffolds, mesenchymal cells and growth/differentiation factors) (FJ, 2011; Gordeladze, Haugen, Lyngstadaas, \& Reseland, 2017). As a potent growth/differentiation factor representative, bone morphogenetic proteins can induce bone regeneration with the expensive technology and high costs as their current weakness; however, it is forecasted that growth/differentiation factors will play a critical role in future regenerative medicine applications (Ishack, Mediero, Wilder, Ricci, \& Cronstein, 2017).

Today, porous materials, which can be obtained from a large number of raw materials, such as zeolites, play a significant role in our life (Mecheri, Hafsi, \& Gherraf, 2018). Zeolites are microporous aluminosilicate compounds and have been used as commercial catalyzers, and ion-exchanging or ion-separating agents (Guo, 
Long, Song, \& Zhu, 2014). It is of volcanic origin, which comprises almost $70 \%$ of silicon oxide (Sochor, Salas, Babula, \& Kizek, 2010). Adsorptions of heavy metals by Zeolites have been largely investigated lately due to its great binding characteristics (Kulkarni, Srinikethan, \& Vidya, 2012), abundance, and low cost (Danehpash, Farshchi, Roayaei, Ghoddousi, \& Hassani, 2018). Medical application of Zeolites would be a new possibility due to their non-toxic nature; therefore, they have successfully been used in tissue engineering as magnetic resonance imaging contrast agents, anti-microbial coverings, drug carrier systems, and growth/differentiation factors $(\mathrm{Li}$, Jiao, Li, \& Guo, 2015). In the study of Bedi et al. (2009), Zeolite coverings on titanium alloy dental implants (Ti6Al4V) showed high corrosive resistance and suppressed the discharge of aluminum and vanadium ions into the human tissues (Li, Jiao, Li, \& Guo, 2015; Bedi, Beving, Zanello, \& Yan, 2009; Bedi, Zanello, \& Yan, 2009). High capability of Zeolites as drug carriers is due to their homogenous microporous structure and also because of their multiple functional groups giving them the binding ability to drug molecules via hydrogen bonds (Amorim et al., 2012; Tavolaro, Riccio, \& Tavolaro, 2013). These features make it possible for carried drugs to diffuse more broadly while loading in the target organ. For example, it has been stated that zeolite can be a carrier in the production of free-flowing choline chloride (Shevtsov, Drannikov, Derkanosova, Borodovicyn, Glebova, \& Gurin, 2017). Also, Zeolites accelerated the production of mineralized matrix and differentiation of fetal osteoblastic cells to mature osteoblasts which shows osteoinductive feature of Zeolites.

MG-63 cells are morphologically fibroblast-like osteosarcoma cells with human origin (Bidar, Tavakol, \& Shahrami, 2008). These cells have been used as experimental models to study osteoblastic cellular functions like extracellular matrix production and binding, alkaline phosphatase activity, and osteocalcin production (Clover \& Gowen, 1994).

It became a great trend to use these experimental cellular models as an adjuvant approach in radical endodontic surgeries after successful application of tissue and bone regenerative techniques in implantology and periodontology (Agrawal, 2017; Ashcroft et al., 2003; Brugnami \& Mellonig, 1999; Hasegawa, Yamato, Kikuchi, Okano, \& Ishikawa, 2005; Tsesis, Rosen, Tamse, Taschieri, \& Del Fabbro, 2011; Washio et al., 2018; Weinreb, Tsesis, Rosen, Taschieri, Del Fabbro, \& Nemcovsky, 2017).

Since there are limited literatures about the effects of Zeolite on the morphology and functions of pre-osteoblastic MG-63 cells, maybe we can introduce new bone enhancer material(s) to bio-engineering processes by this study.

\section{Materials and Methods}

\subsection{Study Design}

In this in vitro experimental trial, MG-63 cells morphologically fibroblast-like human osteosarcoma cells obtained from Pasteur Institute of Iran, Tehran, Iran). There were 6 groups for every test and each time point (24 and 72 hours) based on the Zeolite concentration and presence or absence of Alloplast extract. These groups are considered as below:

$0.1 \mu \mathrm{g} / \mathrm{mL}$ Zeolite with Alloplast (Group A), $0.1 \mu \mathrm{g} / \mathrm{mL}$ Zeolite without Alloplast (Group B), $0.2 \mu \mathrm{g} / \mathrm{mL}$ Zeolite with Alloplast (Group C), $0.2 \mu \mathrm{g} / \mathrm{mL}$ Zeolite without Alloplast (Group D), $0.3 \mu \mathrm{g} / \mathrm{mL}$ Zeolite with Alloplast (Group E), $0.3 \mu \mathrm{g} / \mathrm{mL}$ Zeolite without Alloplast (Group F); there were also three control groups as positive control, negative control, and Alloplast control based on each related test.

\subsection{Cellular Culture}

Purchased MG-63 cells were cultured in complete DMEM (Dulbecco's Modified Eagle Medium) cultures consist of $10 \%$ FBS Gibco, USA), $100 \mathrm{IU} / \mathrm{mL}$ penicillin (Gibco, USA), and $100 \mathrm{mg} / \mathrm{ml}$ streptomycin (Gibco, USA); then, cultured cells were incubated at $5 \% \mathrm{CO}_{2}, 95 \%$ humidity, and $37^{\circ} \mathrm{C}$ temperature till reaching the confluency of $90 \%$ at which time cells were detached by trypsin and EDTA and passaged. MG-63 cells were used to prepare cell suspension at the $4^{\text {th }}$ passage with proper cell density; the cell suspension with density of $20000 \mathrm{cell} / \mathrm{mL}$ was distributed in the wells of 2 plates ( 96 wells per each plate) to perform MTT assay at 24-and 72-hour time points; also, 2 plates ( 24 wells per each plate) were prepared by the same cell suspension to perform alizarin test at 3-and 7-day time points.

\subsection{Cell Suspension and Culture Preparation}

Primary stock solution of Zeolite was prepared by dissolving 30mg Zeolite (Sigma, USA) in 10ml of PBS (Phosphate buffer saline) (Invitrogen, USA) and then sterilized using an autoclave; Zeolite concentrations of $0.1 \mu \mathrm{g} / \mathrm{mL}, 0.2 \mu \mathrm{g} / \mathrm{mL}$, and $0.3 \mu \mathrm{g} / \mathrm{mL}$ were prepared from the primary stock. To create osteogenic culture, we added ascorbic acid $(50 \mu \mathrm{g} / \mathrm{mL})$, beta glycerophosphate $(10 \mathrm{mM})$, and dexamethasone $(100 \mathrm{nM})$ into the sterilized complete culture. Preparation of DMEM culture was done according to the manufacturer's instructions (Merck, 
Germany) and eventually sterilized by $0.2 \mu \mathrm{m}$ filters. We added $100 \mathrm{IU} / \mathrm{mL}$ of penicillin (Gibco, USA) and $100 \mathrm{mg} / \mathrm{mL}$ of streptomycin (Gibco, USA) to the sterilized DMEM culture; in the final step, FBS (Gibco, USA) was added to the culture by the proportion of $10 \%$.

Tetrazolium bromide salt (TBS) $(5 \mathrm{mg} / \mathrm{ml})$ (Sigma, USA) was prepared and sterilized by $0.2 \mu \mathrm{m}$ filters and frozen at $-20^{\circ} \mathrm{C}$ till the test time. At the test time, TBS was diluted with DMEM in a 1:5 dilution ratio.

At a sterile condition, $0.003 \mathrm{~g} / \mathrm{mL}$ MBCP $\beta$-TCP Alloplast granules (Biomatlante, France) were added to culture and incubated in HYSC-Shaker (Korea) at $37^{\circ} \mathrm{C}$ and rotation of 100 rounds/minute to prepare Alloplast extract. For application in the experiment, FBS solution (Gibco, USA) was added to Alloplast extract by the proportion of $10 \%$.

\subsection{MTT Test}

This assay is based on the reduction of a tetrazolium salt, 3-(4,5-dimethylthiazol-2-yl)-2,5-diphenyl tetrazolium bromide (MTT), to (yielding) a colored formazan product by mitochondrial enzymes which present only in living, metabolically active cells (Carmichael, DeGraff, Gazdar, Minna, \& Mitchell, 1987; Cole, 1986).

After the incubation, 96-well plates were screened using an optic microscope (Nikon, Japan) at 4x and 10x magnifications to assure they were non-contaminated. In the next step, culture media and $\beta$-TCP Alloplast were removed from each well and were rinsed by PBS. The MTT salt solution was diluted by the proportion of 1:10 with the culture media, then, $200 \mu \mathrm{L}$ of this solution was added to each well and was incubated for 3 hours with $98 \%$ humidity, temperature of $37^{\circ} \mathrm{C}$, and $5 \% \mathrm{CO}_{2}$. After the incubation time, wells were screened under light microscope to assure that the samples were stained, then, the supernatant was removed and $200 \mu \mathrm{L}$ of DMSO (Sigma, USA) was added to each well. Finally, light absorbance was measured at $570 \mathrm{~nm}$ by ELISA reader device (Anthos 2020, Austria); reference filter was measured at 620nm as the control. (Figure 1)

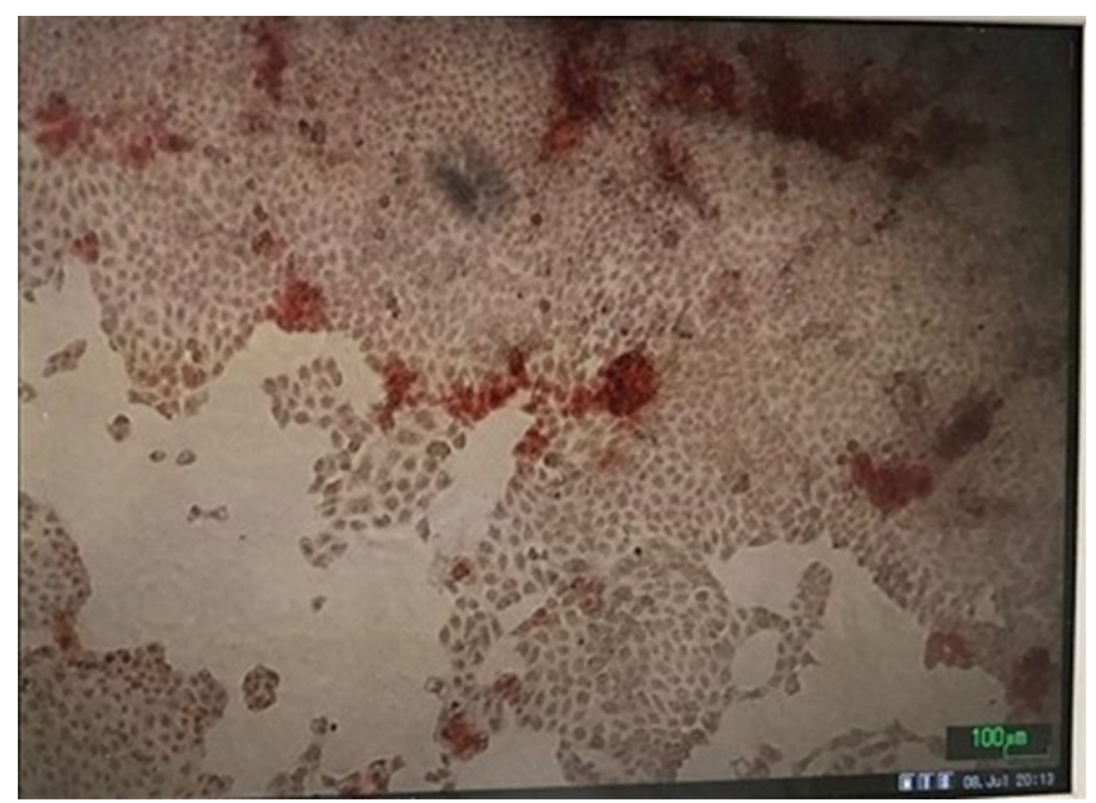

Figure 1. Legend. Creation of calcified nodules in MG-63 cells seen by light microscope (40x magnification). The concentration of zeolite was $0.3 \mu \mathrm{g} / \mathrm{mL}$ with alloplast and at 72 -hours time point

To measure the MTT test results, each group's number was divided by the mean of negative control group without the Alloplast.

\subsection{Alizarin Red Test}

Alizarin red is a stain commonly used to identify calcium containing osteocytes in differentiated cellular culture. (Alizarin red stain (Harleco, Gibbstown, NJ), 2\% solution in distilled water, with $\mathrm{pH}$ of 4.2) (Mc, 1958).

After the incubation, 24-well plates were rinsed by PBS and the DMEM media with the Alloplast were removed from plates. To fix cells, $1 \mathrm{cc}$ of ethanol (70\%) was added to each well for 1 hour. After 1 hour, ethanol was removed and cells were rinsed 2 times with PBS solution for 5 minutes each time. The next step was staining the 
cells by alizarin red $2 \%$ for 30 minutes in the room temperature; hereafter, stain was removed and cells were rinsed 4 times with PBS solution for 5 minutes each time. Finally, each well was screened using light microscope at $4 \mathrm{x}$ and 10x magnification to evaluate cell morphology and calcified nodules which were stained as red or orange.

\subsection{Data Analysis}

SPSS software v.20 was used to analyze data; also, to compare the mean amounts between the study groups One-Way ANOVA and Welch test were used. P value amounts lower than $0.05(\mathrm{P}<0.05)$ were considered as statistically significant. As the ANOVA results were significantly different, Games-Howell tests were used to compare each group pair.

\section{Results}

\subsection{Effect of t Zeolite Concentrations on Cell Proliferation Rate (MTT Test)}

Proliferation rate of MG-63 cells with or without Alloplast at 24- and 72-hours' time points and with different Zeolite concentrations is shown in Table 1.

According to Welch test, there were significant differences in the proliferation rate of MG-63 cells between the study groups $(\mathrm{p}<0.001)$. The results of paired group comparisons at 24 hours showed that solutions with $0.1 \mu \mathrm{g} / \mathrm{mL}, 0.2 \mu \mathrm{g} / \mathrm{mL}$, and $0.3 \mu \mathrm{g} / \mathrm{mL}$ Zeolite with or without Alloplast had significantly higher proliferation rates than positive control groups (distilled water) without Alloplast. In comparison to negative control group (complete culture) with Alloplast, the solutions with $0.1 \mu \mathrm{g} / \mathrm{mL}, 0.2 \mu \mathrm{g} / \mathrm{mL}$, and $0.3 \mu \mathrm{g} / \mathrm{mL}$ Zeolite without Alloplast had significantly higher proliferation rates $(p<0.03)$ and in comparison to negative control group (complete culture) without Alloplast, solutions with $0.1 \mu \mathrm{g} / \mathrm{mL}, 0.2 \mu \mathrm{g} / \mathrm{mL}$, and $0.3 \mu \mathrm{g} / \mathrm{mL}$ Zeolite with Alloplast had significantly lower proliferation rates $(\mathrm{p}<0.05)$. Solutions with $0.1 \mu \mathrm{g} / \mathrm{mL}, 0.2 \mu \mathrm{g} / \mathrm{mL}$, and $0.3 \mu \mathrm{g} / \mathrm{mL}$ Zeolite without Alloplast had significantly higher proliferation rates compared to solutions with $0.1 \mu \mathrm{g} / \mathrm{mL}$ and $0.2 \mu \mathrm{g} / \mathrm{mL}$ Zeolite with Alloplast. Solutions with $0.1 \mu \mathrm{g} / \mathrm{mL}$ and $0.2 \mu \mathrm{g} / \mathrm{mL}$ Zeolite with Alloplast had significantly lower proliferation rates compared to solutions with $0.1 \mu \mathrm{g} / \mathrm{mL}, 0.2 \mu \mathrm{g} / \mathrm{mL}$, and $0.3 \mu \mathrm{g} / \mathrm{mL}$ Zeolite without Alloplast $(\mathrm{p}<0.05)$.

According to the results of ANOVA test, there were significant differences in the proliferation rate of MG-63 cells between the studied groups at 72 hours' time point $(p<0.001)$. Paired group comparisons at 72 hours' time point showed significantly higher proliferation rates in the solutions with $0.1 \mu \mathrm{g} / \mathrm{mL}, 0.2 \mu \mathrm{g} / \mathrm{mL}$, and $0.3 \mu \mathrm{g} / \mathrm{mL}$ Zeolite with or without Alloplast compared to the positive control group (distilled water) without Alloplast $(\mathrm{p}<0.001)$. In comparison to the negative control group (complete culture media) with Alloplast, there was significantly higher proliferation rates in the solutions with $0.1 \mu \mathrm{g} / \mathrm{mL}, 0.2 \mu \mathrm{g} / \mathrm{mL}$, and $0.3 \mu \mathrm{g} / \mathrm{mL}$ Zeolite without Alloplast $(\mathrm{p}<0.001)$. There were significantly lower proliferation rates in the solutions with $0.1 \mu \mathrm{g} / \mathrm{mL}, 0.2 \mu \mathrm{g} / \mathrm{mL}$, and $0.3 \mu \mathrm{g} / \mathrm{mL}$ Zeolite with Alloplast compared to the negative control group (complete culture media) without Alloplast ( $\mathrm{p}<0.001$ ); also the solutions with $0.1 \mu \mathrm{g} / \mathrm{mL}, 0.2 \mu \mathrm{g} / \mathrm{mL}$, and $0.3 \mu \mathrm{g} / \mathrm{mL}$ Zeolite without Alloplast had significantly higher proliferation rates in comparison to the solutions with $0.1 \mu \mathrm{g} / \mathrm{mL}, 0.2 \mu \mathrm{g} / \mathrm{mL}$, and $0.3 \mu \mathrm{g} / \mathrm{mL}$ Zeolite with Alloplast $(\mathrm{p}<0.001)$.

\subsection{Calcium Nodule Formation (Alizarin-Red Test)}

Asteroid-like or polyhedral shape and pseudopodiums are two key features of differentiated osteoblastic cells. The results of alizarin red staining-as a bone regeneration indicator-showed the formation of calcified nodules in solutions with $0.1 \mu \mathrm{g} / \mathrm{mL}, 0.2 \mu \mathrm{g} / \mathrm{mL}$, and $0.3 \mu \mathrm{g} / \mathrm{mL}$ Zeolite with Alloplast and also in the positive control group (distilled water) at 3- and 7-days' time points. (Figure 1)

\section{Discussion}

Zeolites are among bio-ceramic materials which can be applicated as bone scaffolds due to their bone-like feature (Mohammadkhani, Tabesh, \& Houshmand, 2016). Zeolites are divided to synthetic and natural type; synthetic type Zeolites have higher synthesis speed and can be created as microcrystalline or microcrystalline structures. Most of synthetic Zeolites are synthesized at alkali media and hydrothermal conditions with temperature of $-200^{\circ} \mathrm{C}$. Natural Zeolites have bigger particle sizes than the synthetic type. The aim of the present study was to evaluate effects of different Zeolite concentrations on the morphology and function of MG-63 cells with or without MBCP (Macroporous Biphasic Calcium Phosphate) in an experimental model. According to our results, maximum proliferation of MG-63 cells was occurred in the negative control group without Alloplast. Since, the proliferation rate showed no significant difference by increasing Zeolite concentration in similar groups, the Zeolite incrementation could not be toxic to MG-63 cells. The negative control group (complete culture media) without Alloplast consists of adjusted compounds and showed highest proliferation rates of 
MG-63 cells. Lower proliferation rates in solutions with $0.1 \mu \mathrm{g} / \mathrm{mL}, 0.2 \mu \mathrm{g} / \mathrm{mL}$, and $0.3 \mu \mathrm{g} / \mathrm{mL}$ Zeolite might be because of diluted culture ingredients like necessary amino acids, vitamins, and other micro elements; In the other hand, addition of Alloplast resulted in significant reduction of proliferation rates. Also, there was a significant reduction of proliferation rates with addition of Alloplast to the negative control group (complete culture media); this might be because of rapid release of $\mathrm{Ca}^{2+}$ and $\mathrm{PO}_{4}{ }^{3-}$ ions over the physiologic fluids. Rapid solubility of $\beta$-TCP Alloplast lowers accessible surface for ostial cell proliferation (Sanchez-Salcedo, Balas, Izquierdo-Barba, \& Vallet-Regi, 2009). Also it may be possible for these ions to interact with culture ions and disturb tonicity and PH. Yet, there is no evidence of the ion releasing feature for these Alloplast over the 24- and 72-hours' time points and needs to be deal with in future studies. Another possibility could probably be different solubility dynamics between $\beta$-TCP and HA/ $\beta$-TCP. Also, we should consider the biologic activity of Alloplast $\mathrm{s}$ with less than $1 \mu \mathrm{m}$ pores, especially in terms of protein interactions (Vallet-Regí, Arcos, \& Navarrete, 2008). Bigger pores $(>100 \mu \mathrm{m})$ are needed in Alloplast $\mathrm{s}$ to supply enough oxygen level and angiogenesis for the bone structure; therefore, we used MBCP extract with the pore size of 1 to $2 \mathrm{~mm}$ in this study.

Iqbal et al. (2016) in an experimental study on the effect of incremental concentration of Zeolite from 1\% to $10 \%$ (Iqbal et al., 2016); observed an increase in human osteoblastic cell proliferation rate at 3- and 7-day time points.

In a similar study by Kim et al. (2012), after adding BCP (biphasic calcium phosphate) granules in HBSS solution for 1 week, specific small granules began to appear on each BCP granule (Kim et al., 2012). There was less proliferation rates reported in this study which is considered because of rapid release of $\mathrm{Ca}^{2+}$ and $\mathrm{PO}_{4}{ }^{3-}$ and lowering the accessible surface for osteocytes; so, the clinical applications of this ceramic has been limited.

The results of SEM and Von Kossa mineralization in Bedi et al. study (2009) showed better cell attachment and MFI surface mineralization on surfaces with MFI Zeolite coverings than surfaces without this covering (Bedi, Zanello, \& Yan, 2009). These results showed that Zeolite crystals might improve osteointegration of new bone material.

The results of alizarin red staining in our study, as a bone regeneration indicator, showed the formation of calcified nodules in solutions with $0.1 \mu \mathrm{g} / \mathrm{mL}, 0.2 \mu \mathrm{g} / \mathrm{mL}$, and $0.3 \mu \mathrm{g} / \mathrm{mL}$ Zeolite with Alloplast and also in the positive control group at 3-and 7-days' time points. This can be due to $\beta$-TCP Alloplast in the solutions. There were calcified nodules seen in the positive control group because of calcium and other necessary elements for bone formation; but there were no calcified nodules in the negative control group. $\beta$-TCP has been successfully used as a bone substitute in clinical cases for decades due to its osteoconductive feature (Lu \& Zreiqat, 2010). This can scaffold can also induce signaling pathways in addition to its supportive role to osteocytes; it can also set a structural balance by diffusing a lot of $\mathrm{Ca}^{2+}$ and $\mathrm{SO}_{4}{ }^{2-}$ ions and necessary salts for bone formation (Gao et al., 2016).

It is also reported in Iqbal et al. (2016) study by SEM pictures that human osteoblast cells have normal morphology and connected to each other by digitations (Iqbal et al., 2016). Zeolite-hydroxy apatite samples were distributed with elongated morphology on the disc surface and cells had more developed filopodia, so the surface can support cell attachment and growth and had no negative effect on cell viability. These results show the biocompatibility of ZSM-HA samples and prove that they have no side effects on cell viability and morphology. These features can be due to existence of silica at ZSM-HA that can increase protein absorbance needed for bone mineralization process. Bone formation process needs attachment of osteoblasts to ECM surface as the first crucial step to initiate proliferation, differentiation, and secretion of newly formed ECM by mature osteoblasts. Surface texture has indirectly incremental effect on bone mineralization, specific 3D surface defines attachment sites for immature osteoblast colony which secretes ECM proteins to induce osteogenesis.

\section{Conclusion}

The results of present study show that Zeolite can increase proliferation of MG-63 cells (human osteoblast like cells with human osteosarcoma origin) without presence of Alloplast; though, application of both Alloplast and Zeolite (like positive control group) caused creation of calcified nodules in MG-63 cells' culture. It seems that combination of Zeolite with Alloplast maybe enhancing proliferation and function of MG-63 cells.

\section{Acknowledgements}

This research did not receive any specific grant from funding agencies in the public, commercial, or not-for-profit sectors.

\section{Conflict of interests}

The authors declare that there is no conflict of interests regarding the publication of this paper. 


\section{References}

Agrawal, A. A. (2017). Evolution, current status and advances in application of platelet concentrate in periodontics and implantology. World Journal of Clinical Cases, 5(5), 159.

Amorim et al. (2012). Zeolite structures loading with an anticancer compound as drug delivery systems. The Journal of Physical Chemistry C, 116(48), 25642-50.

Ashcroft et al. (2003). Estrogen modulates cutaneous wound healing by downregulating macrophage migration inhibitory factor. J Clin Invest, 111(9), 1309-18.

Bedi, R. S., Beving, D. E., Zanello, L. P., \& Yan, Y. (2009). Biocompatibility of corrosion-resistant zeolite coatings for titanium alloy biomedical implants. Acta Biomater, 5(8), 3265-71.

Bedi, R. S., Zanello, L. P., \& Yan, Y. (2009). Osteoconductive and osteoinductive properties of zeolite MFI coatings on titanium alloys. Advanced Functional Materials, 19(24), 3856-61.

Bidar, M., Tavakol, A. J., \& Shahrami, F. (2008). Evaluation of adhesion and morphologic changes of human osteoblasts exposed to gray MTA, white MTA and Portland cement. Journal of Dental Medicine, 20(4), 300-6.

Brugnami, F., \& Mellonig, J. T. (1999). Treatment of a large periapical lesion with loss of labial cortical plate using GTR: A case report. Int J Periodontics Restorative Dent., 19(3), 243-9.

Carmichael, J., DeGraff, W. G., Gazdar, A. F., Minna, J. D., \& Mitchell, J. B. (1987). Evaluation of a tetrazolium-based semiautomated colorimetric assay: Assessment of chemosensitivity testing. Cancer Res., 47(4), 936-42.

Clover, J., \& Gowen, M. (1994). Are MG-63 and HOS TE85 human osteosarcoma cell lines representative models of the osteoblastic phenotype? Bone, 15(6), 585-91.

Cole, S. P. (1986). Rapid chemosensitivity testing of human lung tumor cells using the MTT assay. Cancer Chemother Pharmacol, 17(3), 259-63.

Danehpash, S., Farshchi, P., Roayaei, E., Ghoddousi, J., \& Hassani, A. H. (2018). Study on the Use of Natural Adsorbents for Oil Spill Removal. J Biochem Tech., Special Issue(2), 59-65.

Denisova, E. V., Suprunchuk, V. E., \& Dronova, A. A. (2017). Biopolymeric materials containing brown algae polysaccharides. Entomol Appl Sci Lett., 4(2), 19-23.

FJ, O. B. (2011). Biomaterials and scaffolds for tissue engineering. Mater Today, 14, 88-95.

Gao et al. (2014). Current progress in bioactive ceramic scaffolds for bone repair and regeneration. Int J Mol Sci., 15(3), 4714-32.

Gao et al. (2016). Beta-tricalcium phosphate granules improve osteogenesis in vitro and establish innovative osteo-regenerators for bone tissue engineering in vivo. Sci Rep., 6, 23367.

Gordeladze, J. O., Haugen, H. J., Lyngstadaas, S. P., \& Reseland, J. E. (2017). Bone tissue engineering: state of the art, challenges, and prospects. Tissue Engineering for Artificial Organs: Regenerative Medicine, Smart Diagnostics and Personalized Medicine, 2, 525-51.

Guo, Y. P., Long, T., Song, Z. F., \& Zhu, Z. A. (2014). Hydrothermal fabrication of ZSM-5 zeolites: Biocompatibility, drug delivery property, and bactericidal property. J Biomed Mater Res B Appl Biomater, 102(3), 583-91.

Hasegawa, M., Yamato, M., Kikuchi, A., Okano, T., \& Ishikawa, I. (2005). Human periodontal ligament cell sheets can regenerate periodontal ligament tissue in an athymic rat model. Tissue Eng., 11(3-4), 469-78.

Iqbal et al. (2016). Nano-hydroxyapatite reinforced zeolite ZSM composites: A comprehensive study on the structural and in vitro biological properties. Ceramics International, 42(6), 7175-82.

Ishack, S., Mediero, A., Wilder, T., Ricci, J. L., \& Cronstein, B. N. (2017). Bone regeneration in critical bone defects using three-dimensionally printed beta-tricalcium phosphate/hydroxyapatite scaffolds is enhanced by coating scaffolds with either dipyridamole or BMP-2. J Biomed Mater Res B Appl Biomater, 105(2), 366-75.

Kim et al. (2012). In situ formation of biphasic calcium phosphates and their biological performance in vivo. Ceramics International, 38(3), 1965-74. 
Kulkarni, R. M., Srinikethan, G., \& Vidya, S. K. (2012). Equilibrium and kinetic studies for the adsorption of cadmium ion on Zeolite 4A. J Biochem Tech., 3(5), S158-S160.

Li, Y., Jiao, Y., Li, X., \& Guo, Z. (2015). Improving the osteointegration of Ti6Al4V by zeolite MFI coating. Biochem Biophys Res Commun, 460(2), 151-6.

Lu, Z., \& Zreiqat, H. (2010). Beta-tricalcium phosphate exerts osteoconductivity through alpha2beta1 integrin and down-stream MAPK/ERK signaling pathway. Biochem Biophys Res Commun., 394(2), 323-9.

Mc, G.-R. S. (1958). Histochemical methods for calcium. J Histochem Cytochem, 6(1), 22-42.

Mecheri, G., Hafsi, S., \& Gherraf, N. (2018). Preparation and Characterization of a Porous Material from Algerian Desert Sand. World J Environ Biosci., 7(1), 69-74.

Mohammadkhani, B., Tabesh, H., \& Houshmand, B. (2016). Investigation on novel applications of zeolites in advanced medical sciences. Research in Medicine, 40(3), 96-108.

Ranganath, A., \& Nasim, I. (2017). Surgical management of a periapical lesion with platelet-rich fibrin - A case report. J Adv Pharm Edu Res., 7(3), 355-357.

Sanchez-Salcedo, S., Balas, F., Izquierdo-Barba, I., \& Vallet-Regi, M. (2009). In vitro structural changes in porous HA/beta-TCP scaffolds in simulated body fluid. Acta Biomater, 5(7), 2738-51.

Shevtsov, A. A., Drannikov, A. A., Derkanosova, A. A., Borodovicyn, A. M., Glebova, I. V., \& Gurin, A. G. (2017). Preparation and application of fodder vitamin additive choline chloride B4 on the basis of dried beet pulp in premix composition. International Journal of Pharmaceutical Research \& Allied Sciences, 6(1), 217-226.

Sochor, J., Salas, P., Babula, P., \& Kizek, R. (2010). Study of changes of chlorophyll fluorescence in lime exposed to abiotic stress. $J$ Biochem Tech., 2(5), S118-S119.

Tavolaro, A., Riccio, I., \& Tavolaro, P. (2013). Hydrothermal synthesis of zeolite composite membranes and crystals as potential vectors for drug-delivering biomaterials. Microporous and Mesoporous Materials, 167, 62-70.

Tsesis, I., Rosen, E., Tamse, A., Taschieri, S., \& Del Fabbro, M. (2011). Effect of guided tissue regeneration on the outcome of surgical endodontic treatment: A systematic review and meta-analysis. J Endod., 37(8), 1039-45.

Vallet-Regí, M., Arcos, D., \& Navarrete, D. A. (2008). Biomimetic nanoceramics in clinical use: From materials to applications: Royal Society of Chemistry.

Washio et al. (2018). In Vivo Periodontium Formation Around Titanium Implants Using Periodontal Ligament Cell Sheet. Tissue Eng Part A., 24(15-16), 1273-82.

Weinreb, M., Tsesis, I., Rosen, E., Taschieri, S., Del Fabbro, M., \& Nemcovsky, C. E. (2017). Evolving new strategies for periodontal, endodontic, and alveolar bone regeneration. Evidence-Based Decision Making in Dentistry: Springer (pp. 109-37).

Yeganeh, A., Athari, B., Tavakoli, N., \& Moghtadaei, M. (2018). Comparison of Polyglycolactic Hydroxyapatite - CHITOSAN Scaffolds with or without Mesenchymal Stem Cells in an In-vivo Study. International Journal of Pharmaceutical and Phytopharmacological Research, 8(1), 69-74.

\section{Copyrights}

Copyright for this article is retained by the author(s), with first publication rights granted to the journal.

This is an open-access article distributed under the terms and conditions of the Creative Commons Attribution license (http://creativecommons.org/licenses/by/4.0/). 